\title{
Treatment of HIV-2 infection with ritonavir/ lopinavir: results at 60 months. A single-center study of 9 patients
}

\author{
Philippe Genet*, Tahar Touahri, Laurence Courdavault, Frédérique Plassart, Juliette Gerbe \\ From $16^{\text {th }}$ International Symposium on HIV and Emerging Infectious Diseases \\ Marseille, France. 24-26 March 2010
}

\section{Background}

In vitro and in vivo data have suggested that ritonavir/ lopinavir is one of the most potent protease inhibitor against HIV-2 infection. Nevertheless, only few clinical reports have been published. So, it seemed to us important to report our clinical experience in 9 patients.

\section{Methods}

We searched in our database patients with HIV-2 who have been treated with ritonavir/lopinavir. 9 patients (4 women and 5 men) were identified. Clinical and biological evolution was analyzed.

\section{Results}

At the time of initiation of lopinavir, median age was 54 (37-66). Median duration of HIV infection was 41,6 months (6-101). Previous median duration of treatment was 29 months (4-51). No patient was naïve of treatment. The median previous number of regimens received was 2 (1-2). 5/9 patients were naïve of protease inhibitors. Initial median CD4 cells were 150 (68-478). Viral load (VL) was under the limit of detection in 6 cases. Reasons for switching to lopinavir were toxicity or intolerance $(n=2)$, absence of efficacy on VL $(n=3)$ or inadequacy of previous treatment $(\mathrm{n}=4)$. In all cases, lopinavir was given in association of 2 NRTIs.

After a median follow-up of 60 months (18-84), no severe side effect was observed. VL under the limits of detection was obtained for all patients except for one patient with a very poor compliance. In this later case, after switching lopinavir to raltegravir, VL remained

\footnotetext{
* Correspondence: genet-philippe@wanadoo.fr
}

$\mathrm{CH}$ Victor Dupouy, Argenteuil, France undetectable. CD4 increased in all cases. The median gain of CD4 from baseline was $+234(+50-+472)$.

\section{Discussion}

Because of the very low frequency of the disease in western countries, data on the treatment of HIV-2 infection are uncommon. For these reasons, treatment of HIV-2 patients remains difficult. So, reports on therapeutic options are very important. Even with a modest number of patients, we confirmed the excellent long-term efficiency of lopinavir for the treatment of HIV-2 patients.

Published: 11 May 2010

doi:10.1186/1742-4690-7-S1-P47

Cite this article as: Genet et al:: Treatment of HIV-2 infection with ritonavir/lopinavir: results at 60 months. A single-center study of 9 patients. Retrovirology 2010 7(Suppl 1):P47.
Submit your next manuscript to BioMed Central and take full advantage of:

- Convenient online submission

- Thorough peer review

- No space constraints or color figure charges

- Immediate publication on acceptance

- Inclusion in PubMed, CAS, Scopus and Google Scholar

- Research which is freely available for redistribution

Submit your manuscript at www.biomedcentral.com/submit
C BioMed Central 